\title{
Inhalts -Verzeichniss.
}

Tafel I und II Vetter-Compass.
A. Entstehung des Wetter-Compasses . . . . . . . . . . . . Seite 5.
B. Beschreibung des Wetter-Compasses . . . . . . . . . . . . 》 6-12.
C. Gebrauchsanweisung
\ $13-15$.
1). Zusammenstellung der Beobachtuugs-Resultate für die Wind-Drehung und das Wetter. . . . . . . . . . . . . . . . . . . \16-17.
E. Wetter-Regeln . . . . . . . . . . . . . . . . . . . 》18 25
F. Eutstehung des Regens . . . . . . . . . . . . . . \ $26-30$. 
